\title{
Six-minute walk test as a tool for assessing the quality of life in patients undergoing coronary artery bypass grafting surgery
}

Teste de caminhada de seis minutos como ferramenta para avaliar a qualidade de vida em pacientes submetidos à cirurgia de revascularização miocárdica

Vanessa Cristina Baptista ${ }^{1}$, Luciana Campanatti Palhares ${ }^{2}$, Pedro Paulo Martins de Oliveira ${ }^{3}$, Lindemberg Mota Silveira Filho ${ }^{4}$, Karlos Alexandre de Souza Vilarinho ${ }^{5}$, Elaine Soraya Barbosa de Oliveira Severino ${ }^{4}$, Carlos Fernando Ramos Lavagnoli ${ }^{6}$, Orlando Petrucci ${ }^{7}$

\section{Abstract}

Objective: Evaluate the quality of life in patients undergoing myocardial revascularization using the sixminute walk test.

Methods: This is a prospective observational study with patients undergoing CABG. We recorded the following clinical variables: the six-minute walk test and the SF36 test. The patients were evaluated at the preoperative time and at 2 months of the postoperative period. Patients were evaluated preoperatively and divided into two groups according to the 6-minute walking test: the group with a walking course of $>350$ meters and the group with a walking course of less than $\mathbf{3 5 0}$ meters at the preoperative time.

Results: The study population included 87 patients. Mean age was similar in both groups $(59 \pm 9.5$ years vs. $61 \pm 9.3$ years, respectively, $P=\mathbf{0 . 2 4}$ ). Distances walked were significantly longer in the group with a walking course of

1. Physical Therapist, University of Campinas (UNICAMP), Campinas, SP, Brasil.

2. Doctorate Degree in Clinical Medicine, Unicamp's Teaching Hospital (Hospital das Clínicas), Campinas, SP, Brazil.

3. Doctorate Degree, assistant professor, Surgery Department, Unicamp's School of Medical Sciences, Campinas, SP, Brazil.

4. Doctorate Degree, assistant physician, Surgery Department, Unicamp's School of Medical Sciences, Campinas, SP, Brazil.

5. Master's Degree, assistant physician, Surgery Department, Unicamp's School of Medical Sciences, Campinas, SP, Brazil.

6. Assistant Physician, Surgery Department, Unicamp's School of Medical Sciences, Campinas, SP, Brazil.

7. Postdoctorate Degree, assistant professor, Unicamp's School of Medical Sciences, Campinas, SP, Brazil.
$>350$ meters compared to the group with a walking course of $<350$ meters after $\mathbf{2}$ months of operation $(436 \pm 78$ meters vs. $348 \pm 87$ meters; $P<\mathbf{0 . 0 1})$. The quality of life was lower in the group with a walking course of $<350$ meters compared to the group with a walking course of $>350$ meters in the preoperative period in the following domains: functional capabilities, limitations due to physical aspects, overall health feelings, vitality, and social aspects. Quality of life improved after two months in both groups.

Conclusions: The six-minute walk test at the preoperative time is associated with the quality of life after two months of coronary artery bypass grafting. In overall, quality of life has improved in all patients. The improvement in the quality of life was greater in those patients with a walking course of $>350$ meters at the preoperative time.

Descriptors: Physical therapy modalities. Indicators of quality of life. Quality of life. Myocardial revascularization.

This study was carried out at the Surgery Department, in the Discipline of Cardiac Surgery, Unicamp's School of Medical Sciences, Campinas, SP, Brasil.

Correspondence address:

Vanessa Cristina Baptista

Rua José Duarte, 220 / 2 - Arruamento Fain José Feres - Campinas, SP, Brasil - CEP 13084-586

E-mail:vanbap@hotmail.com

Foster by São Paulo Research Foundation - FAPESP

Article received: on September 21 2011 Article accepted on February $5^{\text {th }}, 2012$ 


\begin{tabular}{|ll|}
\hline Abbreviations acronyms \& symbols \\
\hline ECC/CPB & Extracorporeal Circulation/Cardiopulmonary bypass \\
DM & Diabetes mellitus \\
SD & Standard Deviation \\
LVEF & Left Ventricular Ejection Fraction \\
AMI & Acute Myocardial infarction \\
BMI & Body Mass Index \\
QOL & Quality of Life \\
MR/CABG & Myocardial Revascularization/ Coronary Artery \\
& Bypass Grafting \\
SF36 & The Medical Outcomes Study 36 - Item Short \\
& Form Health Survey \\
6MWT & Six-Minute Walk Test \\
LV & Left Ventricle \\
MV & Mechanical ventilation \\
\end{tabular}

\section{Resumo}

Objetivo: Avaliar a utilidade do teste de caminhada de seis minutos como indicador prognóstico de qualidade de vida em pacientes submetidos a revascularização do miocárdio.

Método: Estudo prospectivo observacional em pacientes submetidos a operação de revascularização do miocárdio. Foram avaliadas as características clínicas, teste de caminhada de seis minutos (TC6) e questionário para avaliação de qualidade de vida, o questionário SF-36. Os

\section{INTRODUCTION}

Thoracic/Cardiac surgery comprises a series of changes in patients' lives. As it is an invasive procedure, it causes pain and anxiety in both patients and family. In addition, thoracic/cardiac surgery is associated with morbidity and mortality. It includes chronic physical and functional disabilities, that impact on quality of life (QOL) of these patients.

The coronary artery bypass grafting (CABG) aims to increase survival, to relieve symptoms of myocardial ischemia, to improve ventricular function, to prevent myocardial infarction, to recover the patient physically, psychologically, and socially, as well as to prolong patient's life and QOL [1-6].

The improvement of QOL is considered as an outcome to be reached after care practices, as well as public policy actions in health promotion and disease prevention [6]. A melhoria da QV é considerada como um desfecho a ser obtido após práticas assistenciais, bem como nas políticas públicas nas ações de promoção à saúde e de prevenção de doenças [6].

The evaluation and measurement of QOL are important in the process of clinical decision making and determination of therapeutic benefits, a perception the patient has about his/her illness. Besides, it also provides a way to evaluate patient survival [7]. Several reports have demonstrated improvement in the QOL postoperative period of thoracic/ pacientes foram avaliados no pré-operatório e divididos em dois grupos, conforme a distância percorrida no TC6: grupo que caminhou mais de $\mathbf{3 5 0}$ metros e grupo que caminhou menos de 350 metros.

Resultados: Foram incluídos no estudo 87 pacientes. A idade média semelhante em ambos os grupos $(59 \pm 9,5$ anos vs. $61 \pm 9,3$ anos; $P=0,24)$. Os pacientes do grupo $>350$ metros caminharam mais no TC6 após dois meses de operação $(\mathbf{4 3 6} \pm 78$ metros vs. $348 \pm 87$ metros; $P<0,01)$ quando comparado ao grupo $<350$ metros. Observamos que a qualidade de vida era inferior no grupo $<350$ metros em relação ao grupo > 350 metros, no período pré-operatório, nos domínios: capacidade funcional, aspectos físicos, estado geral de saúde, vitalidade e aspectos sociais. A qualidade de vida melhorou após dois meses, em ambos os grupos.

Conclusões: O TC6 no pré-operatório tem correlação com a qualidade de vida após dois meses de revascularização do miocárdio. A qualidade de vida melhorou de forma geral em todos pacientes, sendo maior a melhora da qualidade de vida naqueles que caminharam menos que 350 metros no pré-operatório.

Descritores: Modalidades de fisioterapia. Indicadores de qualidade de vida. Qualidade de vida. Revascularização miocárdica.

cardiac surgery compared to the preoperative period [810]. Thus, objective ways to evaluate the $\mathrm{QOL}$ are important in the overall treatment of patients.

The six-minute walk test (6MWT) is a tool to measure QOL, once its performance may reflect the ability to perform daily activities [11]. This test has been correlated as a prognostic marker in various situations, especially in patients with pulmonary embolism [12,13], for example. The 6MWT is widely used in cardiac rehabilitation in several categories of patients, such as after heart surgery, myocardial infarction, and chronic heart failure. It is also an indicator of the functional state of these medical situations [14].

The objective of this study was to evaluate the usefulness of the 6MWT as a prognostic indicator of QOL in patients undergoing Coronary Artery Bypass Grafting surgery.

\section{METHODS}

\section{Design and Setting}

We conducted a research of prospective observational analysis. We studied 97 patients undergoing elective CABG surgery with or without another associated surgical procedure. We included in the study patients admitted from February 2009 to April 2011. The study was approved by the Research and Ethics Committee of the Unicamp's School of Medical Sciences (CEP-FCM-UNICAMP), under 
Opinion Report Nr. 718/2008, CAAE: 05770146000-0.

Patients were evaluated in two periods of time: the preoperative period and the postoperative period (two months after the operation). All patients were treated by the same surgical and physical therapist team. There were no changes during the treatment before and after surgery that could interfere with the postoperative outcome.

Inclusion criteria were age between 18 and 90 years; elective CABG surgery with or without associated surgical procedures, and patients who agreed to participate by signing the written consent form.

Exclusion criteria were patients undergoing other surgical procedures without associated CABG, unstable angina, or those with medical contraindications to 6MWT.

\section{Measurement of the $Q O L$}

In order to perform the measurement of QOL, we used The Medical Outcomes Study 36-Item Short Form Health Survey (SF36). This is a multidimensional questionnaire, consisting of 36 questions covering eight domains. It aims to reflect the impact of disease on patients' lives in a wide range of populations [8]. The domains evaluated by the questionnaire are: physical functioning, role-physical, bodily pain, general health, vitality, role-emotional, social functioning, and mental health. The questions are based on the perception the patients have of their health status over the past four weeks. In order to reach the results in each domain, the questionnaire analyzes the score obtained on each question, which is then transformed into a scale from zero (lowest score) to 100 (highest score) [15]. The questionnaire was administered by interview on two occasions: preoperatively, and two months after the operation.

\section{The Six-Minute Walk Test (6MWT)}

The 6MWT is a submaximal test that measures the distance the patient can quickly walk on a flat surface in a period of 6 minutes [13]. The test was performed preoperatively and two months after the operation, following the guidelines of the American Society of Thoracic Surgery [16]. Briefly, the test was interrupted at the patient request, and the distance walked was measured.

\section{Analysis Groups}

Patients were divided into two groups based on the distance walked in the 6MWT in the preoperative period. We used a cutoff value of 350 meters. It is the closest value to the average distance walked preoperatively for all patients. In the literature, it is considered a representative value of good or poor functional capacity [17-19]. Thus, data from both groups of patients was compared: the group with a walking course of $>350$ meters and the group with a walking course of $<350$ meters. In this way, we were able to compare both groups.

\section{Statistical Analysis}

Continuous variables are expressed as mean \pm standard deviation. Discrete variables are expressed as frequency and percentage. Both groups were compared when variables were normally distributed. The Student's $t$ test or the Mann-Whitney test was used to compare the groups, as appropriated. Discrete variables were assessed using the Chi-square test.

In order to assess the different domains of the SF-36 questionnaire, we performed a partial correlation analysis two after the operation using the distance walked in the 6MWT before the operation. Next, we performed a correlation analysis. The partial correlation analysed the following variables: age, gender, body mass index (BMI) and the use of beta-blockers preoperatively. Statistical analysis was performed using SPSS for Mac version 18 (SPSS, Chicago, IL, USA).

\section{RESULTS}

Ninety-seven patients were initially included in the study. Ten of these subjects were excluded because three died and seven due to lack of adherence to medical evaluations. The final pool of patients comprised 87 patients.

Table 1 shows demographics data of patients. In demographic variables, we observed differences between the groups only in relation to gender. There were more male patients within the group with a walking course of $>350$ meters and more women within the group with a walking course of $<350$ meters. According to the EuroScore, all study patients were of low and medium risk with no difference between groups.

Table 1. Demographic Data.

\begin{tabular}{lccc}
\hline Variables & $\begin{array}{c}>350 \text { meters } \\
\mathrm{n}=52\end{array}$ & $\begin{array}{c}<350 \text { meters } \\
\mathrm{n}=35\end{array}$ & $P$ \\
\hline Age (years) & $59 \pm 9$ & $61 \pm 9$ & 0.24 \\
Gender & & & $<0.01$ \\
M & $43(83 \%)$ & $15(43 \%)$ & \\
F & $9(17 \%)$ & $20(57 \%)$ & \\
DM & $19(36 \%)$ & $18(52 \%)$ & 0.24 \\
Smoking & $16(31 \%)$ & $9(26 \%)$ & 0.78 \\
BMI (kg/m ${ }^{2}$, mean/SD) & $29 \pm 5$ & $27 \pm 3$ & 0.12 \\
EuroSCORE & $2.3 \% \pm 1.3 \%$ & $2.9 \% \pm 2.8 \%$ & 0.19 \\
LVEF (mean/SD) & $61 \pm 13$ & $56 \pm 13$ & 0.07 \\
Previous AMI & $35(67 \%)$ & $26(74 \%)$ & 0.64 \\
\hline
\end{tabular}

$M=$ male $; F=$ female $; S D=$ standard deviation $; B M I=$ body mass index; $D M=$ diabetes mellitus. $L F E F=$ Left ventricular ejection fraction; $A M I=$ acute myocardial infarction. Data are expressed as mean \pm standard deviation. P: Significance level. Group total as expressed as percentage (\%) 
Table 2. Drugs used in both pre and postoperative period.

\begin{tabular}{|c|c|c|c|c|c|c|}
\hline \multirow[t]{2}{*}{ Drugs } & \multicolumn{2}{|c|}{$\begin{array}{c}>350 \text { meters } \\
\mathrm{n}=52\end{array}$} & \multicolumn{2}{|c|}{$\begin{array}{c}<350 \text { meters } \\
\mathrm{n}=35\end{array}$} & \multicolumn{2}{|c|}{$P$} \\
\hline & Pré & Pós & Pré & Pós & Pré & Pós \\
\hline Beta-blocker & $42(81 \%)$ & $41(79 \%)$ & $28(80 \%)$ & $26(74 \%)$ & 0.85 & 0.81 \\
\hline Diuretic & $16(31 \%)$ & $23(45 \%)$ & $15(48 \%)$ & $23(65 \%)$ & 0.35 & 0.08 \\
\hline Platelet antiaggregant & $6(12 \%)$ & $51(98 \%)$ & & $35(100 \%)$ & 0.09 & 0.84 \\
\hline Statins & $45(87 \%)$ & $48(92 \%)$ & $29(83 \%)$ & $32(91 \%)$ & 0.86 & 0.79 \\
\hline Angiotensin conversing enzyma inhibitor & $15(29 \%)$ & $28(54 \%)$ & $9(26 \%)$ & $16(45 \%)$ & 0.93 & 0.59 \\
\hline Nitrate & $15(29 \%)$ & $1(2 \%)$ & $15(48 \%)$ & - & 0.26 & 0.84 \\
\hline Calcium channel blocker & $5(10 \%)$ & $11(21 \%)$ & $6(17 \%)$ & $15(48 \%)$ & 0.47 & 0.05 \\
\hline Vasodilator & $3(6 \%)$ & $3(6 \%)$ & $6(17 \%)$ & $2(6 \%)$ & 0.17 & 0.64 \\
\hline Anticoagulant & $11(21 \%)$ & $3(6 \%)$ & $13(37 \%)$ & $1(3 \%)$ & 0.13 & 0.90 \\
\hline Angiotensin II receptor blocker & $2(4 \%)$ & $3(6 \%)$ & $3(9 \%)$ & $7(20 \%)$ & 0.64 & 0.08 \\
\hline Antiarrhythmic & $1(2 \%)$ & $4(8 \%)$ & $1(3 \%)$ & $2(6 \%)$ & 0.67 & 0.94 \\
\hline Digitalis & $1(2 \%)$ & $1(2 \%)$ & - & $1(3 \%)$ & 0.84 & 0.65 \\
\hline
\end{tabular}

Data are expressed as mean \pm standard deviation. P: significance level. Group total as expressed as percentage (\%). Beta-blocker $=$ propanolol, atenolol, carvedilol. Diuretic $=$ furosemide, hydrochlorothiazide and spironolactone. Platelet antiaggregant $=$ acetylsalicylic acid and clopidogrel. Statins $=$ simvastatin, pravastatin . Angiotensin conversing enzyma inhibitor $=$ captopril e enalapril. Nitrate $=$ isosorbide mononitrate and propatylnitrate. Calcium channel blocker = amlodipine, diltiazem, verapamil and nifedipine. Vasodilator = hydralazine and methyldopa. Anticoagulant = warfarin, enoxaparin and unfractionated heparin. Angiotensin II receptor blocker = losartan potassium. Antiarrhythmic = amiodarone. Digitalis $=$ digoxin e deslanoside. Drugs were not controlled as to dose and frequency of administration

Table 3. Intra- and postoperative data.

\begin{tabular}{lccc}
\hline Procedures performed & $>350$ meters & $<350$ meters & $\mathrm{n}=35$ \\
& $\mathrm{n}=52$ & $29(83 \%)$ & \\
\hline CABG & $43(83 \%)$ & $2(6 \%)$ & \\
CABG with LV aneurismectomy & $5(10 \%)$ & $1(3 \%)$ & 0.53 \\
CABG with valvar replacement & $3(6 \%)$ & $2(6 \%)$ & \\
CABG with LV aneurismectomy + valvar replacement & $1(2 \%)$ & $1(3 \%)$ & \\
CABG + septal exclusion & & $222 \pm 32$ & 0.64 \\
Surgery duration (minutes) & $220 \pm 33$ & $507 \pm 251$ & 0.60 \\
MV time (minutes) & $512 \pm 330$ & $74 \pm 24$ & 0.18 \\
CABG time (minutes) & $80 \pm 22$ & $58 \pm 21$ & 0.23 \\
Aortic clamping time (minutes) & $63 \pm 21$ & $31 \pm 11$ & 0.44 \\
Ischemia time (minutes) & $35 \pm 12$ &
\end{tabular}

$\overline{M R} / C A B G=$ Myocardial Revascularization/Coronary Artery Bypass Grafting; $L V=$ Left Ventricle $; M V=$ mechanical ventilation; Extracorporeal Circulation/Cardiopulmonary bypass. Data are expressed as mean \pm standard deviation. P: Significance level. Group total as expressed as percentage (\%)

Table 2 shows the drugs used pre and postoperatively, such as beta-blocker, diuretic, digitalis, angiotensin II conversing enzyme, calcium channel blocker, statin, platelet antiaggregant, nitrate, vasodilator, anticoagulant, angiotensin II receptor blocker and antiarrhythmic.

Table 3 shows details on the operation data. It was verified the type of surgery, duration of mechanical ventilation, cardiopulmonary bypass time, ischemia time and aortic clamping.

Among the complications found in the postoperative period are wound dehiscence of the lower limb, acute pulmonary edema, hemothorax, atrial fibrillation, pleural effusion and pneumonia (Table 4).

Table 5 shows the partial correlation with the distance walked in the 6MWT preoperatively, and the data from the SF-36 QOL questionnaire postoperatively. There was a positive correlation with physical functioning $(P<0.01)$, pain $(P=0.04)$ and vitality $(P=0.01)$ postoperatively.

Data on 6MWT are shown in Figure 1. There is an improvement in the distance walked in the postoperative period only in the group with a walking course of $<350$ meters ( $233 \pm 106$ meters vs. $348 \pm 87$ meters, $P=<0.01)$ and 
Table 4. Postoperative complications.

\begin{tabular}{|c|c|c|c|}
\hline Postoperative complications & $\begin{array}{c}>350 \text { meters } \\
n=52\end{array}$ & $\begin{array}{c}<350 \text { meters } \\
n=35\end{array}$ & $P$ \\
\hline Dehiscence of lower limb incision & $2(4 \%)$ & & 0.34 \\
\hline Acute pulmonar edema & $1(2 \%)$ & $1(3 \%)$ & 0.80 \\
\hline Hemothorax & $1(2 \%)$ & - & 0.56 \\
\hline Atrial fibrillation & $1(2 \%)$ & $1(3 \%)$ & 0.39 \\
\hline Pleural efusion & - & $1(3 \%)$ & 0.80 \\
\hline Pneumonia & - & $1(3 \%)$ & 0.38 \\
\hline
\end{tabular}

P: Significance level. Group total as expressed as percentage (\%)

Table 5. Correlation between the walk test vs. the SF-36 questionnaire postoperatively.

\begin{tabular}{lc}
\hline $\begin{array}{c}\text { Controlled Variables } \\
\text { Idade, sexo, IMC e beta-blocker }\end{array}$ & $\begin{array}{c}\text { Distance } \\
\text { walked }(\mathrm{m})^{*}\end{array}$ \\
\hline Physical functioning & $\mathrm{r}=0.29(\mathrm{P}<0.01)$ \\
Role-physical & $\mathrm{r}=0.11(\mathrm{P}=0.31)$ \\
Pain & $\mathrm{r}=0.22(\mathrm{P}=0.04)$ \\
General health & $\mathrm{r}=0.05(\mathrm{P}=0.59)$ \\
Vitality & $\mathrm{r}=0.27(\mathrm{P}=0.01)$ \\
social functioning & $\mathrm{r}=0.14(\mathrm{P}=0.18)$ \\
Role-emotional & $\mathrm{r}=-0.04(\mathrm{P}=0.67)$ \\
mental health & $\mathrm{r}=0.06(\mathrm{P}=0.53)$ \\
\hline
\end{tabular}

$r=$ correlation. $P=$ Significance level. $*$ Distance walked preoperatively in the six-minute walk test

in the group with a walking course of $>350$ meters $(428 \pm 47$ meters vs. $436 \pm 78$ meters, $P=0.40$ ). When comparing the distance walked between groups, it was observed that the group with a walking course of $>350$ meters walked longer in both phases.

With regard to the SF-36 QOL questionnaire, it was observed a significant improvement in QOL in both groups. The group with a walking course of $<350$ meters presented a marked improvement. The group with a walking course of $>350$ meters showed improvement in the following domains: pain, general health, vitality, social functioning and mental health. The group with a walking course of $<350$ meters presented improvement in the following domains functional capacity, role-physical, pain, general health, vitality, social functioning, role-emotional, and mental health. When comparing data from SF-6 between groups ( $>350$ meters vs $<350$ meters), there was a difference in almost all domains, both preoperatively and postoperatively (Table 6).

\section{DISCUSSION}

CABG surgery is a complex operation, and it has an impact on QOL. Changes in QOL may lead to organic, emotional, behavioral, social, and functional alterations. The application of instruments regarding physical or mental

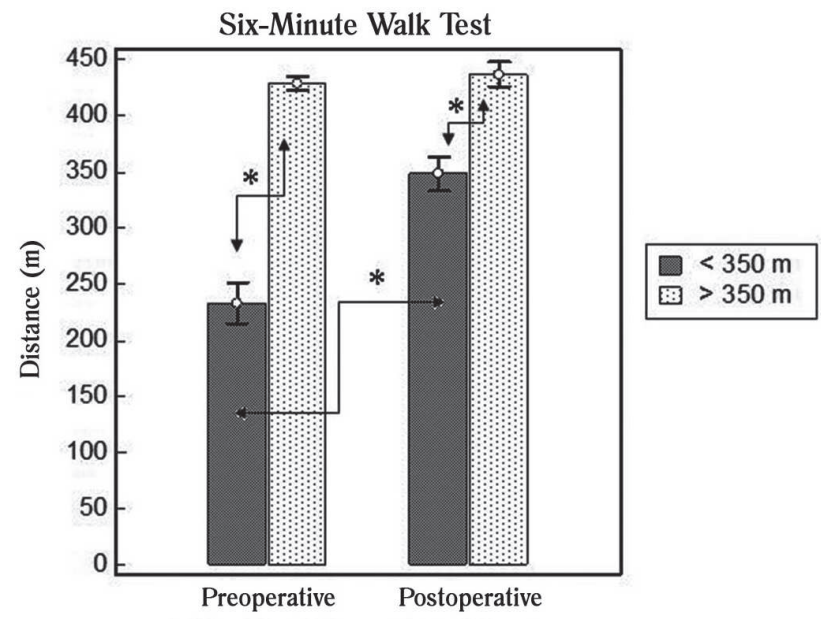

Fig. 1 - Six-minute walk test. Pre and postoperative distance walked in both groups. Data are expressed as mean \pm standard deviation. We observed an improvement in the distance walked in the postoperative period only in the group with a walking course of $<350$ meters $(233 \pm 106$ meters vs. $348 \pm 87$ meters, $P<0.01)$ vs the group with a walking course of $>350$ meters $(428 \pm 47$ meters vs. $436 \pm 78$ meters, $P=0.40) . * P<0.01$.

evaluation is useful to measure possible changes in QOL after certain medical interventions [20]. The SF-36 questionnaire proved to be useful for the assessment of QoL in this study.

In the present study, we found that QOL 2 months after the surgery is associated with 6MWT in the preoperative period. In general, patients who completed a walking course of more than 350 meters preoperatively had better QOL 2 months after surgery. We have also demonstrated that patients who walked less than 350 meters in the 6MWT preoperatively showed improvement in all domains of the SF-36 questionnaire. Nevertheless, these patients still had a QOL inferior to the patients who walked more than 350 meters in the preoperative period in four domains of the SF-36 questionnaire. 
Table 6. Data concerning the quality of life questionnaire SF-36: comparison of preoperative data vs postoperative data in each group and the difference between the groups.

\begin{tabular}{|c|c|c|c|c|}
\hline Domains & & $\begin{array}{l}>350 \text { meters } \\
(\mathrm{n}=52)\end{array}$ & $\begin{array}{c}<350 \text { meters } \\
(n=35)\end{array}$ & $\begin{array}{c}P \\
\geq 350 \text { meters vs. }<350 \text { meters }\end{array}$ \\
\hline \multirow{3}{*}{$\begin{array}{l}\text { Physical } \\
\text { functioning }\end{array}$} & Preoperative & $59 \pm 29$ & $22 \pm 25$ & $<0.01$ \\
\hline & Postoperative & $52 \pm 20$ & $33 \pm 16$ & $<0.01$ \\
\hline & $P$ & 0,16 & 0,02 & \\
\hline \multirow[t]{3}{*}{ Role-physical } & Preoperative & $59 \pm 34$ & $44 \pm 31$ & 0.03 \\
\hline & Postoperative & $64 \pm 25$ & $65 \pm 22$ & 0.83 \\
\hline & $P$ & 0,44 & $<0,01$ & \\
\hline \multirow[t]{3}{*}{ Pain } & Preoperative & $54 \pm 35$ & $43 \pm 35$ & 0.17 \\
\hline & Postoperative & $87 \pm 20$ & $81 \pm 24$ & 0.17 \\
\hline & $P$ & $<0,01$ & $<0,01$ & \\
\hline \multirow[t]{3}{*}{ General health } & Preoperative & $77 \pm 19$ & $64 \pm 19$ & $<0.01$ \\
\hline & Postoperative & $95 \pm 9$ & $93 \pm 11$ & 0.42 \\
\hline & $P$ & $<0,01$ & $<0,01$ & \\
\hline \multirow[t]{3}{*}{ Vitality } & Preoperative & $78 \pm 15$ & $65 \pm 20$ & $<0.01$ \\
\hline & Postoperative & $87 \pm 9$ & $75 \pm 17$ & $<0.01$ \\
\hline & $P$ & $<0,01$ & 0,01 & \\
\hline \multirow[t]{3}{*}{ Social functioning } & Preoperative & $83 \pm 22$ & $64 \pm 32$ & $<0.01$ \\
\hline & Postoperative & $94 \pm 12$ & $85 \pm 18$ & 0.01 \\
\hline & $P$ & $<0,01$ & $<0,01$ & \\
\hline \multirow[t]{3}{*}{ Role emotional } & Preoperative & $75 \pm 31$ & $62 \pm 32$ & 0.06 \\
\hline & Postoperative & $81 \pm 23$ & $79 \pm 24$ & 0.65 \\
\hline & $P$ & 0,14 & $<0,01$ & \\
\hline \multirow[t]{3}{*}{ Mental health } & Preoperative & $74 \pm 15$ & $70 \pm 18$ & 0.25 \\
\hline & Postoperative & $86 \pm 11$ & $79 \pm 14$ & $<0.01$ \\
\hline & $P$ & $<0,01$ & 0,01 & \\
\hline
\end{tabular}

We could not perform a second evaluation two months after the operation in seven patients. In this study, we also observed three deaths in the perioperative period.

The use of the 6MWT proved to be effective. It allows evaluating the patients with a walking course of more or less than 350 meters. This cutoff value used for group analysis was based on several reports found throughout the literature.

Bittner et al. [18], studying patients with chronic heart failure and the 6MWT, observed that patients with a walking course of less than 350 meters had a higher risk of death compared with those with a walking course of than 450 meters in the same walk test. In order to assess prognosis and mortality, other authors also used a distance of 350 meters as a cutoff point for patients with chronic obstructive pulmonary disease, chronic heart failure, and pulmonary hypertension [21,22].

Opasich et al. [14] studied patients undergoing cardiac 
surgery. They found that the distance walked in the 6MWT and a left ventricular ejection fraction greater than $50 \%$ in patients aged 61 to 70 years was on the averaged $330 \pm 98$ meters for men and $255 \pm 93$ meters for women. Finally, in our sample, the average distance walked was $349 \pm 122.8$ meters. For these reasons, we should use the value of 350 meters as a pattern of analysis of the patients.

The use of the cutoff value of 350 meters allowed an objective analysis of both groups of patients and their associations with QOL in the postoperative period two months after surgery.

In the present study, we observed that the preoperative 6MWT was associated with QOL after two months of the operation in patients undergoing $\mathrm{CABG}$. This association was positive in the following domains: physical functioning $(P<0.01)$, pain $(P=0.04)$, and vitality $(P=$ $0.01)$. We used the partial correlation to control age, sex, BMI, and the use of beta-blockers because these variables could affect the distance walked. This mathematical feature allows us to observe the association between 6MWT and QOL without taking into account the variables mentioned previously $[11,19]$.

These findings are similar in patients who underwent the 6MWT during cardiac rehabilitation after acute myocardial infarction [23]. In this study, Hamilton \& Haennel [23] observed that patients undergoing cardiac rehabilitation had a positive correlation of functional capacity, pain, general health, vitality, social functioning, and mental health and the 6MWT.

Another finding of practical interest is that the group with a walking course of less than 350 meters showed an increase in distance walked after two months of the operation. Therefore, has its functional capacity improved (233 \pm 106 meters vs. $348 \pm 87$ meters, $P<001)$.

Both study groups showed improvement in QoL two months after of the operation. The group with a walking distance of less than 350 meters showed an improvement in eight domains of the SF-36 questionnaire, while the group with a walking distance of more than 350 meters showed an improvement in the following domains: pain, general health, vitality, social functioning, and mental health two months after the operation.

Patients with a short walking course in the preoperative period benefited most from the operation when considering QOL. We also observed an improvement in functional capacity only in the group with a walking course of less than 350 meters. In the preoperative period, these patients were weaker and when they had to answer the questions regarding the physical functioning domain, such as climbing stairs, sweep the house, bathing, crouching, walk a block and even up to one kilometer in the last four weeks, many of them could not perform most of these activities without getting tired, or even could not do the activities at all.
In the postoperative period, the patients reported an improvement to perform these activities. The group with the walking course of more than 350 meters had a higher score than the group with a walking course of less than 350 meters $(\mathrm{P}<0.01)$ in the physical functioning domain, a fact that reflected in their daily activities.

In the preoperative period, patients were more anxious and nervous and this reflected in the assessment of QoL. Postoperatively, patients were less nervous and/or anxious and when they answered the SF-36 questionnaire, they reported an improvement in almost all domains of the questionnaire.

For some authors, the patients experience a gradual increase of QoL after one, three, and six months after the operation $[9,10,19,24,25]$. Both groups improved their physical and mental health two months after the operation. The improvement was more evident in patients who were more debilitated preoperatively, i.e., the group with a walking course of less than 350 meters. The improvement of physical and mental components found in this study and assessed through the SF-36 questionnaire is consistent with previous studies in which patients were evaluated within 12 months after the operation [10.26].

Nogueira et al. [27], studying a pool of patients similar to those in our study, compared the use or not of CPB in CABG surgery. They observed no differences in patients who did or did not undergo cardiopulmonary bypass. Nevertheless, they observed a consistently, progressively, and continuously improvement of the QoL [27]. These findings are similar to the present report. However, we did not evaluate patients who underwent CABG without cardiopulmonary bypass. Furthermore, we believe these findings are similar to that found in this work using the 6MWT.

There are reports in the literature regarding the differences in QoL when analyzing the gender of patients. The QOL is lower in women compared with men six months after cardiac surgery $[9,23]$. In the present study, we observed more men in the sample. The individual analysis by gender was not performed due to the limitations of the sample.

Both groups showed an improvement in pain after the operation, which reflected in QOL, once the pain ends up limiting the activities of daily living, physical health, mental, and social health of the patients. When patients were asked about the pain, they generally referred to the pain of angina pectoris. However, at the time of the evaluation, the patients did not have a clinical setting of unstable angina. This is due to the format of the questionnaire. The questions were design to know whether the patient felt pain in the last four weeks, which is the period of time the symptoms appeared. In a recent study evaluating QOL, the authors observed an improvement in patients undergoing cardiac surgery after 
one year in the following domains: pain, functional capacity, and physical and mental health [28].

In the preoperative period, the SF-36 questionnaire showed the highest score in the group with a walking course of more than 350 meters in the following domains: physical capacity $(P<0.01)$, role-physical $(P=0.03)$, general health $(P<0.01)$, vitality $(P<0.01)$, and social functioning $(P<0.01)$. In other words, patients with a longer walking course before the operation have better QOL in these domains in the preoperative period. Two months after the operation, the group with a walking course of more than 350 meters continued to have better QOL compared with the group with a walking course of less than 350 meters in the following domains: physical capacity $(P<0.01)$, vitality $(P<0.01)$, social functioning $(P=0.01)$, and mental health $(P<0.01)$. Patients with a short walking course in the 6MWT presented a worse QOL in both evaluation periods in most domains of the SF36 questionnaire.

The application of the SF-36 questionnaire, in spite of being adapted to the Portuguese language, presented understanding difficulties for some of the patients. However, the observer was trained to assist the patient to answer the questionnaire. The observer was instructed to interfere as little as possible.

Data from this study contribute to the knowledge of QoL in patients undergoing CABG surgery and its relationship with the 6MWT. Although QoL assessments are to be carried out by a subjective questionnaire, they have provided us with important information about the patient's perception of their health.

The patients' follow-up was performed by the same team that started physical therapy and medical treatment. The interviews on QOL were conducted by the same researcher, what contributed to improve the reliability of the results.

\section{CONCLUSION}

CABG surgery improved the QOL in all patients. The improvement was greater in patients who walked less than 350 meters preoperatively. The preoperative 6MWT has correlation with QOL only two months after CABG surgery.

\section{REFERENCES}

1. Nery RM, Martini MR, Vidor CR, Mahmud MI, Zanini M, Loureiro A, et al. Alterações na capacidade funcional de pacientes após dois anos da cirurgia de revascularização do miocárdio. Rev Bras Cir Cardiovasc. 2010;25(2):224-8.
2. Iglézias JCR, Chi A, Talans A, Dallan LAO, Lourenção Júnior A, Stolf NAG. Desfechos clínicos pós-revascularização do miocárdio no paciente idoso. Rev Bras Cir Cardiovasc. 2010;25(2):229-33.

3. Cantero MA, Almeida RMS, Galhardo R. Análise dos resultados imediatos da cirurgia de revascularização do miocárdio com e sem circulação extracorpórea. Rev Bras Cir Cardiovasc. 2012;27(1):38-44.

4. Noyez L, de Jager MJ, Markou AL. Quality of life after cardiac surgery: under researched research. Interact Cardiovasc Thorac Surg. 2011;13(5):511-4

5. Bittar OJNV. Qualidade de vida após revascularização do miocárdio. Rev Bras Cir Cardiovasc. 1992;7(1):1-8.

6. Monteiro R, Braile DM, Brandau R, Jatene FB. Qualidade de vida em foco. Rev Bras Cir Cardiovasc. 2010;25(4):568-74.

7. Abelha FJ, Santos CC, Barros H. Quality of life before surgical ICU admission. BMC Surg. 2007;7:23.

8. Helito RA, Branco JN, D'Innocenzo M, Machado RC, Buffolo E. Qualidade de vida dos candidatos a transplante de coração. Rev Bras Cir Cardiovasc. 2009;24(1):50-7.

9. Peric V, Borzanovic M, Stolic R, Jovanovic A, Sovtic S, Djikic $\mathrm{D}$, et al. Quality of life in patients related to gender differences before and after coronary artery bypass surgery. Interact Cardiovasc Thorac Surg. 2010;10(2):232-8.

10. Grady KL, Lee R, Subacius H, Malaisrie SC, McGee EC Jr, Kruse J, et al. Improvements in health-related quality of life before and after isolated cardiac operations. Ann Thorac Surg. 2011;91(3):777-83.

11. Reesink HJ, van der Plas MN, Verhey NE, van Steenwijk RP, Kloek JJ, Bresser P. Six-minute walk distance as parameter of functional outcome after pulmonary endarterectomy for chronic thromboembolic pulmonary hypertension. J Thorac Cardiovasc Surg. 2007;133(2):510-6.

12. Bautmans I, Lambert M, Mets T. The six-minute walk test in community dwelling elderly: influence of health status. BMC Geriatr. 2004;4:6.

13. Enright PL, McBurnie MA, Bittner V, Tracy RP, McNamara R, Arnold A, et al. The 6-min walk test: a quick measure of functional status in elderly adults. Chest. 2003;123(2):387-98

14. Opasich C, De Feo S, Pinna GD, Furgi G, Pedretti R, Scrutinio $\mathrm{D}$, et al. Distance walked in the 6-minute test soon after cardiac surgery: toward an efficient use in the individual patient. Chest. 2004;126(6):1796-801.

15. Ciconelli RM, Ferraz MB, Santos W, Meinão I, Quaresma MR. Tradução para a língua portuguesa e validação do 
questionário genérico de qualidade de vida SF-36 (Brasil SF36). Rev Bras Reumatol. 1999;39(3):143-50.

16. ATS Committee on Proficiency Standards for Clinical Pulmonary Function Laboratories. ATS statement: guidelines for the six-minute walk test. Am J Respir Crit Care Med. 2002;166(1):111-7.

17. Rostagno C. Six-minute walk test: independent prognostic marker? Heart. 2010;96(2):97-8.

18. Bittner V, Weiner DH, Yusuf S, Rogers WJ, McIntyre KM, Bangdiwala SI, et al. Prediction of mortality and morbidity with a 6-minute walk test in patients with left ventricular dysfunction. SOLVD Investigators. Jama. 1993;270(14):1702-7.

19. De Feo S, Tramarin R, Lorusso R, Faggiano P. Six-minute walking test after cardiac surgery: instructions for an appropriate use. Eur J Cardiovasc Prev Rehabil. 2009;16(2):144-9.

20. Terashima K, Yoshimura Y, Hirai K, Kusaka Y. QOL-associated factors in elderly patients who underwent cardiovascular surgery. Environ Health Prev Med. 2012;17(2):131-8.

21. Rasekaba T, Lee AL, Naughton MT, Williams TJ, Holland AE. The six-minute walk test: a useful metric for the cardiopulmonary patient. Intern Med J. 2009;39(8):495501.

22. Cote CG, Casanova C, Marin JM, Lopez MV, Pinto-Plata V, de Oca MM, et al. Validation and comparison of reference equations for the 6-min walk distance test. Eur Respir J. 2008;31(3):571-8.

23. Hamilton DM, Haennel RG. Validity and reliability of the 6minute walk test in a cardiac rehabilitation population. $\mathbf{J}$ Cardiopulm Rehabil. 2000;20(3):156-64.

24. Lindquist R, Dupuis G, Terrin ML, Hoogwerf B, Czajkowski S, Herd JA; POST CABG Biobehavioral Study Investigators, et al. Comparison of health-related quality-of-life outcomes of men and women after coronary artery bypass surgery through 1 year: findings from the POST CABG Biobehavioral Study. Am Heart J. 2003;146(6):1038-44.

25. Kapetanakis EI, Stamou SC, Petro KR, Hill PC, Boyce SW, Bafi AS, et al. Comparison of the quality of life after conventional versus off-pump coronary artery bypass surgery. J Card Surg. 2008;23(2):120-5.

26. Gjeilo KH, Wahba A, Klepstad P, Lydersen S, Stenseth R. Recovery patterns and health-related quality of life in older patients undergoing cardiac surgery: a prospective study. Eur J Cardiovasc Nurs. 2011.

27. Nogueira CRSR, Hueb W, Takiuti ME, Girardi PBMA, Nakano T, Fernandes F, et al. Qualidade de vida após revascularização cirúrgica do miocárdio com e sem circulação extracorpórea. Arq Bras Cardiol. 2008;91(4):238-44.

28. Falcoz PE, Chocron S, Stoica L, Kaili D, Puyraveau M, Mercier M, et al. Open heart surgery: one-year self-assessment of quality of life and functional outcome. Ann Thorac Surg. 2003;76(5):1598-604. 